\title{
Training on the Utilization of Citrus Fruits in Making Dodol to Improve the Welfare of Citrus Farmers in Lau Riman Village, Tanah Karo Regency
}

\section{Warsani Purnama Sari}

Universitas Medan Area, Indonesia

warsanipurnama@yahoo.com

\begin{abstract}
Citrus fruit is one of the typical Indonesian fruits that is cheap and easy to obtain, as well as one of the daily dessert fruit of the community. One of the Citrus fruit producer locations in North Sumatra is Tanah Karo Regency, where the Citrus orchards are the main livelihood of the community. Citrus Fruit itself was developed in the era of 1990 in Tanah Karo which is able to eradicate poverty and improve the education of Tanah Karo youths. Lau Riman Village, Tiga Panah Sub-district, within +/$17 \mathrm{~km}$ from Kabanjahe, is a producer of Citrus orchards in besides the Merek and Munthe areas. The Citrus orchard in Lau Riman Village surrounds the village with a total of approximately eighty eight Family Heads. Siamese honey citrus or Karo itself is known as a famous sweet citrus, has a sweet smell or aroma, rough citrus flesh, rind that is easy to peel and the appearance of the fruit is quite attractive. The purpose of Community Partnership Program activities is to assist partners in improving the skills and innovation of citrus to packaging technology so that it is expected to create economic independence and increase business income. Based on observations of partners, there are several problems encountered, including: 1) There is no innovation in citrus crop yields, 2) Conventional marketing that is only awaiting the arrival of buyers, 3) Skills and limited knowledge of the utilization of citrus crops. Specific targets in the Community Partnership Program activities that result; 1) Fruit Dodol innovation 2) Marketing Strategy 4) scientific articles published in ISSN journals. The method used to achieve the Community Partnership Program activity goals is the method of education, production training, and packaging and marketing assistance. This activity was carried out for citrus fruit farmers in Lau Riman Village, Tiga Panah Sub-district, Tanah Karo Regency, which is approximately $75 \mathrm{~km}$ from the University of Medan Area. The choice of location is because in the village there are communities that depend on the economic life of citrus farming and there has been no innovation to citrus fruits other than just planting, harvesting, and selling fresh citrus fruits.
\end{abstract}

Keywords

innovation; creativity, marketing

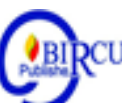




\section{Introduction}

Citrus fruit is one of the typical Indonesian fruits that is cheap and easy to obtain, as well as one of the daily dessert fruit of the community. One of the Citrus fruit producing locations in North Sumatra is Tanah Karo Regency, North Sumatra, where the Citrus fruit orchards are the main livelihood of the population. Citrus Fruit itself was developed in the era of 1990 in Tanah Karo which is able to eradicate poverty and improve the education of Tanah Karo youth. Lau Riman Village, Tiga Panah Sub-district, within +/- $17 \mathrm{~km}$ from Kabanjahe, is a producer of Citrus orchards in besides the Merek and Munthe areas. The Citrus orchard in Lau Riman Village surrounds the village with a total of approximately eighty eight Family Heads. Siamese honey citrus or Karo itself is known as a famous sweet citrus, has a sweet smell or aroma, rough citrus flesh, rind that is easy to peel and the appearance of the fruit is quite attractive.

The abundance of Karo Citrus can be seen from the frequency of harvesting up to two times a year where one citrus fruit tree is able to produce a minimum of 50 kilograms to 100 kilograms of citrus fruits. Besides the good quality of the fruit causes high demand for oranges. Based on data from balitjestro.litbang.pertanian.go.id (Research Institute for Citrus Plants and Subtropical Fruits), Demand for Citrus Fruits in North Sumatra is relatively high, which in 2013 alone shipped the number of Citrus fruits to cities in Sumatra, Java, and Bali can reach 80-100 trucks a day.

The empowerment of citrus fruits in Tanah Karo is relatively conventional. That is, farmers concentrate only on planting, harvesting and selling citrus harvests. Abundant harvests in the Citrus Garden, Lau Riman Village, Tanah Karo causing its own problems, unsold citrus fruits are allowed to fall to rot or are sold at very cheap prices, which are only Rp.5,000, - per kilogram, while based on information from partners that, each time a farmer is able to produce $500 \mathrm{~kg}$ of fresh orange, and out of all the fruit that is harvested, approximately ten percent are not sold, left to rot, making it wasteful. Based on this information, of course, there are many redundant citrus which can actually be processed to produce extra income. So far, the community has only relied on citrus harvests, and alternatives to planting vegetables around citrus trees such as chilies, Dutch eggplants, bitter mustard greens, coffee, and tomatoes to supplement their income. Seeing the enormous potential in the yield of citrus fruit, of course the activity of removing citrus fruit that does not sell or by letting the fruit rot and fall is an unproductive and wasteful activity. So there needs to be involvement of academics in making citrus processing breakthroughs into other products of economic value, given the potential number of workers absorbed is quite potential, then with the assistance of processing and innovation of citrus fruit products will be able to improve the welfare of citrus fruit farmers

Based on the above background, it is felt that activities need to be carried out to encourage the creativity of citrus farmers in utilizing unsold citrus fruits in order to become economical and high-value products. The partners of this activity are citrus fruit farmers in Lau Riman Village, Tanah Karo Regency.

Based on observations and statements from various parties, the problems that can be identified are as follows:

\section{a. Limited Skills and Knowledge on the Utilization of Citrus Crops}

So far, citrus farming is still very conventional, meaning that partners only focus on how to make citrus dense or abundant, and this is consistent with the results of interviews with partners, that so far even if there is counseling or assistance from government agencies, NGOs and academics only it is more about how citrus fruits can be of good quality, the use of appropriate pesticides, or other agricultural techniques aimed at increasing the productivity of 
citrus fruits. However, partners did not consider alternatives to processing citrus as innovative products, it was proven that when the harvest was overflowing, many citrus that were not sold just went bad. Of course this is very unfortunate, considering the citrus fruit is a fruit that is very familiar to people's daily lives.

\section{b. There is No Innovation in Citrus Yields}

Partners have a mindset that for innovation is costly, time-consuming, and the possibility to get profits that are uncertain, or it can be said that partners avoid the risk of loss from innovation experiments.

\section{Review of Literature}

\section{Marketing}

Marketing is a social and managerial process in which individuals and groups get what they need and want by creating, offering, and exchanging products of value to others (Kotler, 2000). Marketing management is the process of planning and implementing thought, pricing, promotion and channeling ideas, goods and services to create exchanges that satisfy individual and organizational goals (Kotler, 2000). According to Freddy Rangkuti (2006) the main elements of marketing can be classified into three main elements:

\section{a. The elements of the competition strategy are grouped into 3:}

1) Market segmentation, The act of identifying and forming separate groups of buyers or consumers

2) Targeting, an act of selecting one or more market segments to enter.

3) Positioning, determining market position, the purpose of positioning is to build and communicate the competitive advantage of products in the market into the minds of consumers.

b. The elements of marketing tactics are grouped into 2:

1) Differentiation, which is related to how to build marketing strategies in various aspects of the company.

2) Marketing mix, which is related to activities regarding product, price, promotion, and place.

\section{c. The marketing value elements are grouped into 2:}

1) Brand, which is the value associated with the name or value that is owned and attached to a company.

2) Process, which is the value that is blessed with the principle of the company to make every employee involved and have a sense of responsibility in the process of satisfying consumers, both directly and indirectly.

\section{Research Methods}

The method applied in this study are workshop, training and direct practice of citrus dodol processing. The workshops and training involved experts or experts who were competent in the field of food and nutrition processing. The steps taken in Community Service activities include several stages which are summarized in the following table: 
Table 1. Stages of Community Service Activities

\begin{tabular}{|c|l|l|l|l|}
\hline No & $\begin{array}{l}\text { Implementation } \\
\text { of Activities }\end{array}$ & \multicolumn{1}{|c|}{ Approach Method } & \multicolumn{1}{|c|}{ Target } & \multicolumn{1}{|c|}{$\begin{array}{c}\text { Partner } \\
\text { Participation }\end{array}$} \\
\hline 1 & $\begin{array}{l}\text { Licensing } \\
\text { arrangements to } \\
\text { the Village }\end{array}$ & Licensing & $\begin{array}{l}\text { Urban Village } \\
\text { Permit organizes } \\
\text { activities }\end{array}$ & $\begin{array}{l}\text { Provide a place } \\
\text { and } \\
\text { accommodation }\end{array}$ \\
\hline 2 & $\begin{array}{l}\text { Training in } \\
\text { making dodol }\end{array}$ & $\begin{array}{l}\text { Training on healthy and } \\
\text { hygienic production of } \\
\text { dodol }\end{array}$ & $\begin{array}{l}\text { Citrus fruit } \\
\text { based product } \\
\text { innovation. }\end{array}$ & $\begin{array}{l}\text { Provide a place, } \\
\text { and follow } \\
\text { practical activities }\end{array}$ \\
\hline 3 & $\begin{array}{l}\text { Technology / e- } \\
\text { commerce based } \\
\text { marketing } \\
\text { training }\end{array}$ & $\begin{array}{l}\text { Training and } \\
\text { introduction of } \\
\text { information technology, } \\
\text { introduction of social } \\
\text { media as a promotional } \\
\text { media }\end{array}$ & $\begin{array}{l}\text { Ready-to-use } \\
\text { technology- } \\
\text { based marketing }\end{array}$ & $\begin{array}{l}\text { Provide a place, } \\
\text { and follow } \\
\text { practical activities }\end{array}$ \\
\hline
\end{tabular}

The first stage begins with the licensing process whereby the activity team coordinates with Lau Riman village officials to obtain permits and other support for the success of the activity, in addition to that the coordination with the official aims to get the team to obtain complete data on the participants in the village environment. The activity involved eighty-eight citrus farmers living in Lau Riman village.

The second stage, the team formed a team consisting of citrus dodol instructors, who are experts in the field of food processing and nutrition, and formed an online marketing instructor team, the activities carried out first were citrus fruit preparation training, the contents of which were training in making dodol. Hygienic and suitable for consumption, as for this activity the team prepared the following ingredients: thick coconut milk, brown sugar, glutinous rice flour, rice flour, fresh citrus fruit, citrus leaves, white sugar and salt. Along with the necessary cooking utensils. After the training activities were completed, participants were assigned to experiment cooking processed citrus dodol with various creations. The instructor team accompanies, guides and directs and provides solutions if problems arise during practical assignments

Then proceed with the third stage, which is online marketing training, after the training in making dodol is finished, followed by marketing training, the material is the introduction of emarketing using social media and the team provides training on how to design attractive images or photos, which are shared on social media.

At the end of the activity, the Team evaluated the results of the training and the participants also gave an evaluation of this training. After the activity was completed according to plan, the team reminded again about the utilization of the abundant citrus harvest so that it would not be wasteful and have economic value.

\section{Discussion}

The output of community service activities in terms of training in making citrus dodol can be extra income and is expected to be a provision for citrus farmers to develop citrus fruit innovations so as to increase family income, as well as minimize the number of rotting citrus as a result of not selling on the market. In the field of marketing, citrus farmers are able to use social media well in order to maximize the promotion of selling citrus dodol nationally. From 
an academic point of view, this service can be held at a national seminar level and published in an accredited national journal.

Evaluation of community service activities is carried out in the following manner: namely an evaluation of the process and an evaluation of the results. Evaluation of the process can be seen from the seriousness and perseverance of the participants in carrying out practical tasks that is participants are very enthusiastic about participating in training activities with many questions to the instructor. Then, the participants remained eager to follow each activity by seeing the number of participants who did not change from the number of times the activity was held. Evaluation of the results is an examination of the work of the participants, in the evaluation of the results found that many participants have not been able to make dodol properly such as: dodol texture that is too hard or soft, bad taste, to the dodol aroma that is less pleasant. This is understandable because this activity is the first activity introduced to the citrus farmers of Lau Riman Village.
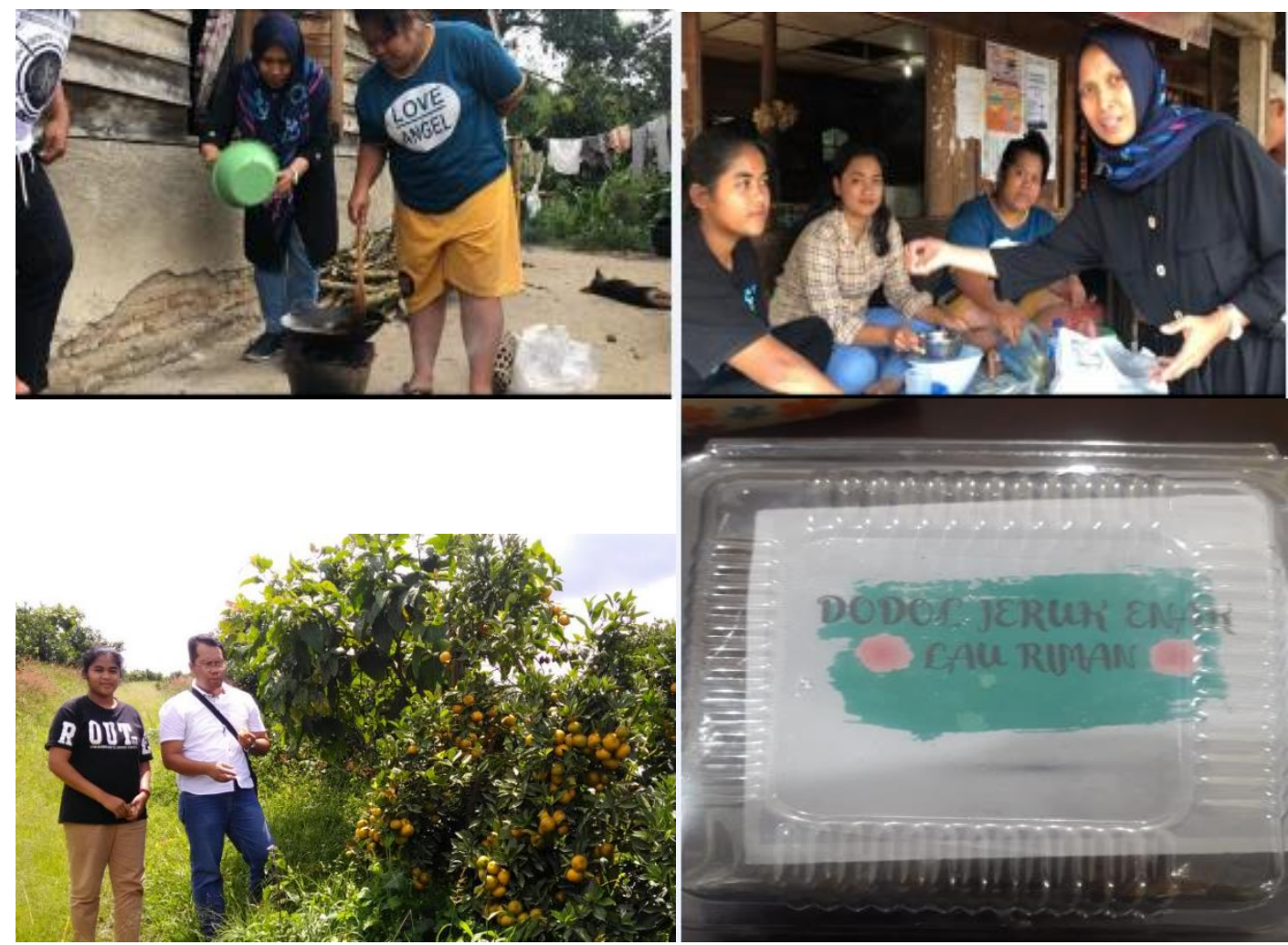

Figure 1. Training in making dodol Citrus Activities

The majority of the training participants wanted the sustainability of the training program because it was deemed necessary in addition to filling in the blanks of time, also because some participants were still not satisfied with the results of dodol made in the training, besides this activity could also bring additional income.

\section{Supporting and Inhibiting Factors}

\section{a. Supporting Factor}

Community Service Activities have been run well with the support of various factors, namely:

1) Effective teamwork 
Communication between team members took place smoothly and effectively so that the team's coordination in the process of preparation, division of tasks, and training could take place well, besides that the competence of each instructor in providing material was quite good by seeing the enthusiasm of partners participating in the activities without feeling bored.

2) Commitment of participants

The trainees, who generally consisted of housewives, citrus farmers enthusiastically participated in the activity until it was finished. During the dodol-making assignment session, participants actively asked questions and completed the tasks that were given well and according to the instructor's instructions.

3) Good Reception from the Community.

Participants' interest was quite high, there was a demand to do activities related to the training of processed citrus products in the next period due to the participants' curiosity about the creation of citrus fruits.

\section{b. Inhibiting Factor}

The inhibiting factor in this activity is the limited time and cost, given the location of the training and the agency of the activity team is quite far, so it cannot hold training activities with a longer time.

\section{Conclusion}

From the activities of community service in the form of training in the utilization of citrus fruits in making dodol, the following conclusions can be made:

a. The training process is in the form of direct practice of making dodol, which begins with an introduction to the ingredients needed in the cooking process and provides a simulation of making citrus dodol.

b. The training activities were followed by assignments to participants to immediately practice how to make dodol by adding the creativity of each participant both in terms of taste, form, and aroma.

c. The output in this activity is the ability of partners to process citrus fruits in making dodol food products, accredited national journals, and national seminars

\section{References}

Kartanto Mardi (2012), Pembangunan Perindustrian Indonesia. Erlangga : Jakarta

Nurul Qomariah (2012), Kualitas Pelayanan dan Citra Institusi Terhadap Kepuasan dan Loyalitas Pelanggan. Jurnal Aplikasi Manajemen. Vol. 10 No.1

Poerwadarminta. (2012). Kamus Umum Bahasa Indonesia. Penerbit PN. Balai Pustaka. Jakarta

Simamora, Bilson. (2013) Riset Pemasaran (Falsafah, Teori, dan Aplikasi). Rineka Cipta Jakarta

Sukadji (2010). Industri Dalam Perkembangannya. Balai Pustaka, Jakarta

Undang - Undang Nomor 8 Tahun 1999. Perlindungan Konsumen. (Lembaran Negara Tahun 1999, No 42, Tambahan Lembaran Negara Nomor 3281)

Perda Nomor 3 Tahun 2003. Retribusi Tera dan Tera Alat Ukur, Takar, Timbang, dan Perlengkapannya (UUTP), Metrologi Legal serta Pengujian Barang Dalam Keadaan Terbungkus. Medan 